\title{
Consumer Complaints And Complaint Forums Employed In The South African Motor Vehicle Service Industry: A Survey Of The Literature \\ Michel M. Koekemoer, University of South Africa, South Africa
}

\begin{abstract}
A South African consumer who owns a motor vehicle will need to have it serviced at a motor vehicle service dealership. The level of service experienced by consumers is not always satisfactory, leaving the consumer dissatisfied and wanting to complain about the poor service. The complaint forums available to South African consumers can roughly be divided into two categories, namely those established under South African law (which include the National Consumer Tribunal; the National Consumer Commission; the Motor Industry Ombud of South Africa; a consumer court; an alternative dispute resolution agent; and an ordinary court); and other traditional complaint forums (which include complaint websites and complaints made to the dealer directly). When deciding on the most appropriate complaint forum, consumers must consider the following factors: the cost of and time spent on the complaint process; the complexity of the rules and procedures associated with each complaint forum; the effective functioning of each forum; and the relief that the consumer can expect to receive from the complaint forum. This study found that when measured against these factors, consumers are left with few viable complaint forums. The structure and functioning of the existing complaint forums remains far from perfect. However, inroads have been made to improve the current complaint forums. Further improvements will only be achieved through a concerted effort by all the industry players. Such collaboration between them will ensure that South African consumers in the motor vehicle service industry will be ranked amongst the best protected consumers in the world.
\end{abstract}

Keywords: Consumer Complaints; Motor Vehicle Service Industry; Complaint Forum

\section{INTRODUCTION}

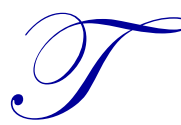

he decision to purchase a motor vehicle is probably one of the most exciting but expensive decisions that a South African consumer may make. There are approximately forty motor vehicle manufacturers that import and distribute vehicles within South Africa (National Association of Automobile Manufacturers of South Africa [NAAMSA], 2013) (hereinafter referred to as 'the NAAMSA list'), which means that South Africans are spoilt for choice when deciding on which motor vehicle to purchase. Generally, in order to guarantee that this expensive item retains its value and reliability, the vehicle must be serviced at regular intervals. However, not all motor vehicle service dealerships render satisfactory service, leaving the consumer dissatisfied with the service and burdened with additional costs, in order to have the motor vehicle serviced properly. A consumer then ends up complaining about the poor service received, mainly to rectify the specific situation or issue (Hoffman et al., 2009). In most cases, the first port of call would be to complain to the motor service dealership itself, but where to from there if this proves futile?

Legislation such as the Consumer Protection Act of 2008 (hereinafter referred to as 'the CPA') and National Credit Act of 2005 (hereinafter referred to as 'the NCA') have created additional complaint forums for consumers. South African consumers need to be better educated about these additional forums, in order to not only 
make consumers aware of the available forums, but also to enable consumers to navigate their way through the sometimes complex rules and procedures of each complaint forum.

It is possible to refer a complaint to more than one complaint forum, and the consumer's choice of a complaint forum may be influenced by, inter alia, the following factors: the cost of and time spent on the complaint process; the complexity of the rules and procedures associated with each complaint forum; the effective functioning of each forum; and the relief that the consumer can expect to receive. This study will provide a synopsis of the complaint forums available to South African consumers within the motor vehicle service industry, ${ }^{1}$ taking these above factors into account.

\section{PURPOSE OF THE STUDY AND RESEARCH METHODOLOGY}

The purpose of this study is to analyse the complaint forums available to South African consumers within the motor vehicle service industry. The specific objective of this research is to analyse the cost of and time spent on the complaint process; the complexity of the rules and procedures associated with each complaint forum; the effective functioning of each forum; and the relief that the consumer can expect to receive after making use of a complaint forum. This study makes use of a literature survey of South African law. This specifically includes the CPA and the relevant industry-specific codes passed under the CPA, motor industry reports, and an analysis of information obtained from certain third-party complaint websites and the websites of the motor vehicle manufacturers listed by the National Association of Automobile Manufacturers of South Africa (hereinafter referred to as 'NAAMSA') as motor vehicle importers and distributers within South Africa. When the study required a detailed industry analysis (as was the case with complaints lodged on complaint websites and internal complaint procedures of motor vehicle manufacturers), the sample was limited to the forty motor vehicle manufacturers on the NAAMSA list.

\section{COMPLAINT FORUMS UNDER SOUTH AFRICAN LAW}

\subsection{Background to the Current Legal Protection Afforded to South African Consumers}

Historically, consumer protection provisions have not provided adequate redress for South African consumers (Jacobs, Stoop, \& Van Niekerk, 2010). Such provisions have failed to address all the legal issues faced, and as the provisions have been located in different legal resources, this has made it difficult for the average consumer to enforce his or her fundamental consumer rights (ibid). However, the partial codification of the consumer law provisions was generally welcomed by South African consumers when the CPA came into effect. The CPA created certain new complaint forums available to consumers to enforce their consumer rights. Merely knowing which complaint forums are available can be daunting for the average consumer. However, the average consumer will face bigger challenges than merely knowing which forums are available. These challenges include having to determine which complaint forum has jurisdiction (already a 'foreign' word for non-lawyers) for hearing the complaint, and then having to navigate one's way through the sometimes complex rules and procedures associated with each complaint forum.

In general, under the CPA, a consumer complaint can be referred to either the National Consumer Tribunal (hereinafter referred to as 'the Tribunal'); the National Consumer Commission (hereinafter referred to as 'the Commission'); the Motor Industry Ombudsman of South Africa (hereinafter referred to as 'MIOSA', being the applicable industry ombud); the Consumer Goods and Services Ombud, a consumer court, ${ }^{2}$ if there is one; or an alternative dispute resolution forum.

After the consumer is acquainted with complaint forums under the CPA, he or she needs to examine the following before deciding on the forum(s) best suited to resolving their complaint: the cost of and time spent on the complaint process; the complexity of the rules and procedures associated with each complaint forum; effective

\footnotetext{
${ }^{1}$ The motor vehicle service industry, for the purpose of this study, will entail repair or replacement services to consumers in respect of motor vehicles.

${ }^{2}$ This would be a court established either at national or provincial level that would only hear consumer matters and not other types of civil or criminal matters.
} 
functioning of each forum; and the relief that the consumer can expect to receive. In some instances, it is possible for a consumer to make use of more than one of the CPA's established forums, which could result in forumshopping. A matter can, for example, be heard by MIOSA and then referred to the Commission. However, according to Section 116 of the CPA, a decision taken by the Commission can only be overturned by the Tribunal on appeal, but it would not be possible to bring two fresh actions based on the same set of facts simultaneously to both the Tribunal and Commission. ${ }^{3}$ What follows is a discussion of the complaint forums that are available under South African law.

\subsection{National Consumer Commission}

Section 85 of the CPA established the Commission mandated in terms of Section 99 of the CPA to enforce compliance with the provisions of the CPA within the jurisdiction of the whole of South Africa.

\subsubsection{Complexity of the Rules and Procedures used by the Commission}

Any consumer can file a complaint with the Commission in the prescribed electronic form, by directly submitting it on the website of the Commission (National Consumer Commission [Commission], 2013). The form is written in plain language, making it easily understandable for the average consumer.

In terms of Section 72 of the CPA, the Commission can then decide to do the following with the complaint received from the customer: (a) issue a notice of non-referral to the consumer if the complaint appears to be frivolous or without merit; (b) in order to assist the parties to resolve the issues, refer the complaint to an alternative dispute resolution agent, a provincial consumer protection authority, or a consumer court; (c) refer the complaint to another regulatory authority, for example the Tribunal, with jurisdiction over the matter for investigation; or (d) direct an inspector to investigate the complaint as quickly as possible.

In the event that an inspector is appointed and requires either documentary or oral evidence, the Commission can issue a summons for a person able to provide such evidence to either present the evidence verbally or make the actual document available (see Section 102 of the CPA). It appears from the wording of Section 102 that the Commission can issue such a summons, but that the consumer will be responsible to serve (meaning deliver) the summons on the person who holds the required evidence. Furthermore, the CPA requires that the serving of the summons must be done in the same manner as would be the case for a criminal matter heard before a magistrate's court. In other words, a summons can only be served on a person by the Sheriff of the High Court. This will result in additional costs on the part of the consumer. The fees that a Sheriff can charge are prescribed by the South African Board of Sheriffs (Sheriffs, 2013).

In the event that the Commission decides not to investigate the complaint, the consumer may be forced to make use of another complaint forum, which could have resolved the matter in the first place. In addition, a consumer must be aware that under Section 116 of the CPA, it is not possible to refer the matter to either the Tribunal or a consumer court after the complaint has already been heard by the Commission, except when the decision of the Commission is appealed.

\subsubsection{The Cost of and Time Spent on Lodging a Complaint with the Commission}

A consumer can lodge a complaint with the Commission free of charge. However, the consumer may incur some additional costs relating to the serving of documents on the dealership to notify them of the proceedings and the cost of having to pay the Sheriff of the High Court to serve a summons in the manner discussed in 3.2.1.

Lodging an electronic complaint via the Commission's website is not time consuming. However, based on the discussion in 3.2.3 below, consumers tend to spend a significant amount of time following up on the status of their complaint after lodging it with the Commission.

\footnotetext{
${ }^{3}$ This is in line with the legal principle of 'res iudicata. The principle merely states that a matter based on the same set of facts cannot be referred to more than one court.
} 


\subsubsection{Effective Functioning of the Commission}

Even though the Commission received ten thousand complaints, of which already a thousand were resolved six months after its establishment, the jury is still out on the effectiveness of the Commission (Booi, 2011). The alleged ineffectiveness of the Commission was reported on in the press. More specifically, dissatisfaction was expressed regarding the manner in which the Commission operated under the leadership of the former Commissioner (Barron, 2012). In a quarterly progress report presented to the governmental portfolio committee on trade and industry on 24 January 2012, information on the functioning of the Commission was summarised. It reported that the Commission answered approximately 8,000 calls per month, but could not answer close to 20,000 telephone calls due to lack of capacity and only managed to resolve 4,124 complaints for that quarter (Commission, 2012). This report listed some of the operational challenges faced by the Commission, namely: (a) insufficient budget, impacting on the efficiency of the office; (b) insufficient capacity in relation to human capital with relevant expertise; (c) lack of sufficient information technology systems, which includes lack of computers and telephones; and (d) lack of a properly functioning system to deal with the magnitude of complaints (complaints are still handled manually) (Commission, 2012).

Furthermore, it does seem ironic that consumers complain about the Commission, which was established to provide aggrieved consumers with a forum for complaints, on Hellopeter.com, a third-party website (for a definition of this concept, see 5.2 below). An analysis of comments posted on Hellopeter.com about the Commission over a twelve month period (April 2012-April 2013) indicated that out of the forty reports posted, thirty seven were complaints and only three were compliments. A total of $65 \%$ of the complaints were related to the Commission not responding adequately or, in some instances, not at all to consumer complaints lodged with the Commission (Hellopeter, 2013).

The Commission has only been in existence for over a year, so one can only hope that it becomes more effective as time progresses. Furthermore, one must bear in mind that the true purpose of the Commission is to develop consumer policy, rather than to hear consumer complaints. Consumers need to consider other forums such as the Tribunal for relief while the Commission is busy resolving its capacity issues. In addition, one must bear in mind that once a matter has been referred to the Commission, it is no longer possible to refer the same matter also to the Tribunal. Furthermore, the Consumer Goods and Services Ombud was established on 18 March 2013, with the intention of also relieving the pressure currently being experienced by the Commission.

\subsubsection{Relief that can be Obtained from the Commission}

In the event that the matter was investigated by the Commission without hearing any evidence from either side, and the Commission and the motor service dealer agree on the terms of a proposed settlement agreement, the Commission must still refer this settlement agreement to the Tribunal or a consumer court in order for the settlement agreement to become a consent order that is legally enforceable. The Commission can also issue a compliance notice to a dealership whom the Commission has reasonable grounds to believe has engaged in prohibited conduct. Such notice can request a dealership to bring their practice in line with the provisions of the CPA. However, if the dealership fails to comply, the Commission cannot impose a fine itself. The Commission must request either the Tribunal to impose an administrative fine or the National Prosecuting Authority to prosecute it as an offence relating to prohibited conduct in terms of Section 110(2) of the CPA.

\subsubsection{Development of an Industry Code}

The Commission must consult the public and relevant stakeholders before recommending a proposed industry code to the Minister of Trade and Industry (hereinafter referred to as 'the Minister') and industry for approval. Such a code can provide for an alternative dispute scheme, and the Minister can accredit such a scheme as an 'ombud with jurisdiction.' The Commission has already gone through this process for the motor vehicle industry and a draft South African Automotive Industry Code was published for public comment on 15 February 2013 (hereinafter referred to as 'the Code') (General Notice 113 of 2013. GG 3611415 February 2013). It is likely that the final version of the Code will be published soon. 
Complaints relating to the service of a motor vehicle are also regulated under this Code as the "repair or replacement service to consumers in respect of vehicles' is included under the definition of 'automotive industry.' The Code is important for consumers for the following reasons: (a) prescribes certain performance standards that suppliers must comply with; (b) establishes two regulatory bodies, the Motor Industry Advisory Board (hereinafter referred to as 'MIAB') and MOISA; (c) provides the consumer with a complaint procedure to be followed; and (d) makes it compulsory for suppliers to develop an internal complaint procedure, of which schedule 5 of the Code provides guidelines to motor vehicle manufacturers.

\subsection{National Consumer Tribunal}

The Tribunal derives its legislative mandate from the NCA and as of 1 April 2011, also from the CPA. Parties that can refer a matter to the Tribunal for adjudication include the National Credit Regulator, the Commission, consumers, credit providers under the NCA, debt counselors, and credit bureaus. The decisions passed by the Tribunal carry the same weight as decisions passed by a High Court of South Africa (National Consumer Tribunal [Tribunal], 2012).

\subsubsection{Complexity of the Rules and Procedures used by the Tribunal}

The average consumer may need to seek legal advice before taking a complaint to the Tribunal. The Tribunal procedure resembles a court process, which would require more technical knowledge on the part of the consumer.

\subsubsection{The Cost of and Time Spent on Lodging a Complaint with the Tribunal}

The Tribunal procedure resembles that of a court. A consumer may therefore need to employ the services of a legal professional to help the consumer to navigate through the process. This will result in additional costs for the consumer.

The Tribunal only hears matters relating to complaints under the NCA and CPA, compared to ordinary courts that hear matters on any aspect of the law. The volume of matters heard by the Tribunal will be far less than a normal court, making the Tribunal roll schedule less congested. The Tribunal has also established a roll schedule of at least two matters being heard per week and for matters requesting for interim relief to be heard as soon as possible (Tribunal, 2012).

\subsubsection{Effective Functioning of the Tribunal}

The Tribunal aims to provide accessible adjudication and redress in all matters referred to the Tribunal. During the reporting period of 2011/2012 (1 March 2011 to 29 February 2012), the Tribunal received 2,205 applications. Media reports on the effectiveness of the judgment of the Tribunal have contributed to an increased awareness among consumers of the Tribunal's work (Tribunal, 2012).

During the period of 2011/2012, only one matter heard before the Tribunal involved a complaint against a supplier in the motor vehicle service industry. In Peugeot Citroen South Africa (PTY) LTD t/a t/a Citroen South Africa v National Consumer Commission Case No: NCT/4062/2012/101 (1) (P) (date of hearing 3 August 2012), the applicant, Peugeot, applied for the setting aside of a compliance notice issued by the Commission, which request was granted by the Tribunal.

It appears, from the annual reports of the Tribunal, as if it is functioning more effectively than the Commission. This may prove to be a more effective complaint forum available to consumers than the Commission. Furthermore, the hearing of consumer complaints is more the responsibility of the legislative mandate than that of the Commission. However, the Tribunal procedure resembles a court process, which would require a more advanced knowledge of South African Law to master. This proves to be impossible for the general consumer. 


\subsection{A Person or Entity Providing Conciliation, Mediation or Arbitration Services to Assist in the Resolution of Consumer Disputes}

Conciliation, ${ }^{4}$ mediation, ${ }^{5}$ or arbitration ${ }^{6}$ (collectively known as alternative dispute resolution forums) can be employed to resolve consumer disputes. The Retail Motor Industry Organisation (hereinafter referred to as 'the RMI') is such an entity, which attempts to achieve an amicable mediated resolution to disputes in a manner that is cost-effective for both parties concerned (Retail Motor Industry Organisation [RMI], 2013). The RMI currently has 7,500 members and seeks to find ways to improve the motor industry for its members, which ultimately improves the conditions for consumers (RMI, 2013).

The RMI can also hear disputes that involve a non-RMI member (RMI, 2013). An introductory study revealed that the RMI is currently the only alternative dispute resolution forum available to consumers in the motor vehicle service industry. However, the inclusion of alternative dispute resolution forums under the CPA may encourage the establishment of more such forums. The parties also have more of a say in the final outcome of this complaint forum, as they have an input in the adjudicator and prescribed dispute resolution processes. Alternative dispute resolution forums are less formal and, in most instances, more cost-effective than complaints referred to ordinary courts.

\subsubsection{Complexity of the Rules and Procedures used by the RMI}

The complaint form can be downloaded from the website of the RMI (RMI, 2013). The template of this form is written in plain language and the average consumer should, in principle, be able to complete it. Furthermore, the RMI website also provides an option whereby consumers can post their comments online for a RMI representative to respond to. The details of this process are not publicly known. One can only hope that the process is similar to a standard alternative dispute resolution forum. It should be noted that this ADR process is not a legal procedure and that no legal presentation is allowed (RMI, 2013).

\subsubsection{The Cost of and Time Spent on Lodging a Complaint with the RMI}

The RMI charges an administration fee of R285, and does not mention which party will have to pay the costs of investigating the matter. However, the complaint requests that supporting documents be included, so one can assume that the consumer will have to carry the costs of compiling technical reports.

\subsubsection{Effective Functioning of the RMI}

No annual reports were published that could be used to analyse the effective functioning of the RMI. However, an analysis of comments posted on Hellopeter.com about the RMI over a twelve month period (May 2012-June 2013) indicated that out of the sixteen reports posted about the RMI, fifteen were complaints and only one was a compliment (Hellopeter, 2013). The complaints mostly either related to a lack of interest in resolving the dispute or the perception of partiality on the side of the mediators.

\subsubsection{Relief that can be Obtained from the RMI}

As the ADR process is non-legal, the RMI cannot enforce the settlement agreement reached between the consumer and motor vehicle dealer. In the event that the settlement agreement is breached, the consumer will have to escalate the breach of the agreement to other adjudicating bodies such as the Tribunal or MIOSA.

\footnotetext{
${ }^{4}$ The person who adjudicates is called a conciliator. Conciliation does not have legal standing and witnesses are not called or evidence led. The conciliator plays a limited role and the aim is to get parties to make concessions.

${ }^{5}$ It is possible to legally enforce the outcome of mediation. Witnesses can be called and evidence led. However, the decision of the mediator is not binding upon the parties.

${ }^{6}$ Arbitration is more structured than conciliation and mediation. The parties usually agree on an arbitration procedure. Witnesses can be called and evidence led. The decision of the arbitrator is final and binding upon the parties, and it is not possible to appeal against an arbitration decision.
} 


\subsection{Complaints to Court (Including Consumer Courts)}

There were no reported cases (meaning cases reported by either one of the legal publishers, namely Juta or Butterworths) in 2012 dealing with complaints under the CPA against a supplier in the motor vehicle service industry. Even though no cases were reported, the Tribunal adjudicated matters relating to the CPA, which has created a legal precedent in terms of the provisions of the CPA (National Consumer Tribunal, 2012).

Easy access to courts for South African consumers may prove to be limited. Court proceedings can be lengthy (mostly due to the court roll being congested) and costly (mainly due to the fact that an attorney or advocate needs to be employed to take the matter to court). These disadvantages can deter the average consumer from following this route.

Furthermore, the process in the consumer courts is similar to that of the Tribunal (see Section 73(3) of the CPA), and the judgments of the Tribunal have the same legal status as high court judgments. However, fewer matters are currently being heard by the Tribunal. The Tribunal process may be quicker compared to a court process. Referring a complaint to court is a suitable avenue for a consumer who has the available time and financial means to litigate against a large motor vehicle manufacturer. The average consumer may find that the free redress offered by other complaint forums such as MIOSA is a more appropriate complaint forum.

\subsection{Motor Industry Ombudsman of South Africa ('MIOSA')}

The Department of Trade and Industry recognised the need to have an industry-funded dispute resolution forum that consumers could approach before taking a complaint to the Tribunal (DTI, 2009). MIOSA has already been operational for more than ten years and provides an independent and free dispute resolution service for motor vehicle industry consumers. MIOSA also educates consumers and suppliers on the complaint procedures to be followed.

\subsubsection{Complexity of the Rules and Procedures used by MIOSA}

In general, the informal approach followed by an ombudsman usually results in a large number of complaints being resolved more quickly (Mellville, 2010). This seems to be true of MIOSA, especially since it received 24,952 complaints for 2011, of which 10,150 complaints were resolved during the initial contact made with the consumer (MIOSA, 2011).

The complaint procedure is started by completing a complaint form that can be downloaded from the MIOSA website. The form cannot be completed electronically, as is the case with the Commission complaint form. The completed form can either be e-mailed, sent by post, or hand-delivered to MIOSA. Initially, after the complaint is lodged, the parties are encouraged to reach an amicable settlement. If this does not happen, any party can declare a dispute within fourteen days of the breakdown of party negotiations. The complainant will then submit a dispute declaration to MIOSA, which the other party needs to respond to in writing within fourteen days. A MIOSA employee adjudicates over the matter and if the parties are unable to agree on the rules of adjudication, MIOSA will decide on the rules to be followed during the adjudication process. Parties are allowed to make use of a legal representative to appear on their behalf, but as the rules and procedures are not that complex, this is not a necessity.

\subsubsection{The Cost of and Time Spent on Lodging a Complaint with MIOSA}

A complaint can be referred to MIOSA free of charge. MIOSA does not charge for adjudicating the dispute and an employee of MIOSA usually adjudicates over the matter. However, MIOSA has reserved the right for itself to still determine that some of the costs of the dispute are included as part of the award provided by MIOSA (meaning that the party that lost may pick up the cost for adjudicating the matter). Furthermore, when MIOSA receives a complaint that requires an investigation of a technical nature, the complainant will have to pay the fees of the technical assessor or technician who investigates the matter. The fact that a consumer may be left carrying the costs of adjudication can deter a consumer from referring a complaint to MIOSA. 
The procedural deadlines set by MIOSA ensure that a complaint is resolved speedily. In addition, as mentioned in 3.6.1, a large number of complaints are resolved during the first contact with MIOSA, thus saving the time of these consumers.

\subsubsection{Effective Functioning of MIOSA}

Early 2012 saw the introduction of a new telephone system and an upgrading of the MIOSA complaints system. MIOSA received 24,952 complaints for 2011, of which 10,150 complaints were resolved during the initial contact made with the consumer (MIOSA, 2011).

The 2011 Annual Report did not provide a detailed breakdown of the nature of the complaints. Therefore, it was not possible to ascertain how many of the 24,952 complaints were specifically related to the repair or replacement services to a motor vehicle. However, the report included a summary of some of the complaints received relating to the service or repair of motor vehicles and how they were resolved. Table 1 below reflects the type of complaints and the remedies proposed by MIOSA. The outcome in each case is indicative of the effectiveness of MIOSA as a complaint forum in the motor vehicle industry.

Table 1: Case Studies of Complaints Resolved by MIOSA in 2011 that Related to Repair or Replacement Services to a Motor Vehicle (Adapted from the MIOSA 2011 Annual Report)

\begin{tabular}{|l|l|}
\hline \multicolumn{1}{|c|}{ Case Study 1 } & \multicolumn{1}{c|}{ Outcome } \\
\hline $\begin{array}{l}\text { The owner requested the dealer to attend to a differential oil } \\
\text { leak. The dealer repaired the leak. After 38 000km's the } \\
\text { differential broke and the owner took the vehicle back to the } \\
\text { dealer. However, the owner did also service the differential } \\
\text { in his own workshop. }\end{array}$ & $\begin{array}{l}\text { Outcome 1: Effectively Resolved } \\
\text { MIOSA found that it was likely that the technician who } \\
\text { serviced the differential at the owners' workshop failed to } \\
\text { secure the drain plug, resulting in the oil leak. Both parties } \\
\text { accepted this outcome. }\end{array}$ \\
\hline $\begin{array}{l}\text { The customer requested a dealer to fit a second-hand engine } \\
\text { to a vehicle. After receiving the vehicle back, it made } \\
\text { terrible noises and was towed to the dealership. An } \\
\text { independent inspection showed that the engine was not } \\
\text { second-hand, but a reconditioned old engine. }\end{array}$ & $\begin{array}{l}\text { Outcome 2: Effectively Resolved } \\
\text { replace it at no cost to the consumer. }\end{array}$ \\
\hline $\begin{array}{l}\text { The consumer purchased a pre-owned vehicle with a 1 } \\
\text { month/1000km dealer warranty. The vehicle's transmission } \\
\text { broke after the expiry of the dealership warranty. The } \\
\text { consumer repaired the transmission, but the dealer refused to } \\
\text { refund the consumer. }\end{array}$ & $\begin{array}{l}\text { MIOSA relied on Sections 55 and 56 of the CPA. The cost of } \\
\text { the repair was split between the consumer and dealer, as the } \\
\text { consumer did not approach the dealer before the repairs were } \\
\text { made. However, the damage was not caused by regular wear } \\
\text { and tear. }\end{array}$ \\
\hline $\begin{array}{l}\text { A consumer purchased a pre-owned vehicle that developed } \\
\text { noises and excessive smoke 1 month after purchase, due to a } \\
\text { broken timing chain. }\end{array}$ & $\begin{array}{l}\text { The engine failure was due to poor workmanship and the } \\
\text { dealer was ordered to repair the vehicle free of charge. }\end{array}$ \\
\hline
\end{tabular}

\subsection{Consumer Goods and Services Ombud}

This Ombud will hear complaints that are related to the retail, manufacturing, and wholesale sectors. The office has been operational since 18 March 2013, but Advocate Neville Mellville was only appointed as Ombud on 1 June 2013. It is envisaged that the ombudsman will deal with consumer complaints against suppliers within the consumer goods and services industry, including the retail, manufacturing and wholesale sectors (Anon, 2013). It is hoped that the Ombud will relieve some of the pressure currently being experienced by the Commission. Since this forum has only been in operation since 18 March 2013, no data is available and the effectiveness of this forum is merely speculative.

\section{OTHER COMPLAINT FORUMS}

Consumers may also want to exhaust avenues not necessarily developed under South African law. A discussion of some of these forums follows. 


\subsection{Direct Complaints to the Motor Service Manufacturer}

Literature suggests that there are six different dimensions of organisational responses to complaints, namely timeliness, facilitation, redress, apology, credibility, and attentiveness, which organisations must pay attention to (Davidow, 2003). However, consumer legislation adds another dimension that needs to be considered, namely legal compliance. In terms of the Code (see the discussion in 3.2.5 above), suppliers will be obliged to establish an internal complaints handling process, notify consumers of the complaint process, train staff on the process, and make a reasonable effort to resolve the complaint within thirty days after receiving it. Schedule 5 of the Code includes internal complaint handling guidelines that suppliers will have to follow as soon as the Code comes into operation. It is unfortunate that the Code does not contain sanctions that will apply if the supplier does not establish an internal complaint handling process. This begs the question as to what will motivate suppliers to establish such an internal complaints process.

Furthermore, consumers may not want to complain to the motor service manufacturers for various reasons, which could either relate to the inconvenience of the actual complaint process or the fact that they do not know where and how to complain (Harrison-Walker, 2001). Logic dictates that manufacturers must have some form of complaint procedure in place, but the issues of inconvenience and lack of the details of the complaint process may be best resolved by informing consumers of the internal complaints process on the website of the selected motor manufacturers. The websites of the NAAMSA list of manufacturers were therefore perused to determine if the manufacturers publicised their internal complaint procedures on their websites. This analysis showed that none of the manufacturers on the NAAMSA list made reference to an internal complaint handling procedure on their websites.

\subsection{Gripe Sites}

The Internet provides a platform, through the use of corporate complaint sites (commonly referred to as 'gripe sites'), on which consumers can share their experiences of customer dissatisfaction with the motor vehicle service industry with other consumers (Harrison-Walker, 2001). Bailey (2004) defines corporate complaint websites as places "where consumers can go to voice their concerns about different corporations, marketing actions, and brands." Complaint websites are usually the first forum on which consumers lodge a complaint (Harrison-Walker, 2001).

A Google search for the term 'complaint about poor service' retrieved 94,300 results. Such a high number of search results indicate that consumers are likely to complain online. Hellopeter.com was included in the 94,300 results from Google, and is regarded as "the most powerful customer service website in the world" (Cheales, 2013). In 2009, 327,000 people visited the website every month (Financial Mail, 2009). To lodge a comment or a complaint, the customer is required to $\log$ in with a user name and password (which may or may not be their real name). The person or entity being complained about can then pay a minimal fee to have a right of response on the website to the complaint of the consumer.

This study only examined the motor vehicle service complaints or comments made about manufacturers on the NAAMSA list on Hellopeter.com for the period April 2012-April 2013. During the period under review, there were 5,926 postings for the forty manufacturers on the NAAMSA list. The majority of comments were complaints. The 5,926 postings outweighed the number of complaints dealt with by the Tribunal and Commission, but is considerably less than the complaints referred to MIOSA for adjudication.

Hellopeter.com provided the motor vehicle manufacturers with an opportunity to answer these consumer complaints. It is interesting to note that only nine of the forty manufacturers on the NAAMSA list are listed as companies who respond to complaints made about them on Hellopeter (Hellopeter.com, 2013). However, posting a complaint may still provide the intended redress for a consumer. It may be sufficient redress for a consumer to have the applicable motor vehicle manufacturer 'named and shamed.' The effectiveness of this method would therefore depend on what the consumers aim to achieve. As it appears that motor manufacturers do not comment online, the only consumer remedy that is achieved is 'brand tarnishment.' 
It is suggested that $72 \%$ of potential consumers examine an organisation's reputation online (Bustos, 2009). Therefore, it could be in the best interests of a motor vehicle manufacturer to respond to consumer comments on gripe sites. Although gripe sites cannot guarantee the desired remedy, it is often the most cost-effective and fastest complaint forum from a consumer's perspective.

The key question with which consumers are faced in this regard is the following: Should this be the forum of last resort or first instance?

\section{DISCUSSION}

This research has implication both for managers of motor manufacturers and consumers. The managerial implications of this research reinforce the fact that a motor vehicle manufacturer must aim to provide satisfactory service to consumers, but this is an unattainable goal. Manufacturers must be aware of the different complaint forums, both legal and non-legal, so that they are able to deal with a complaint in the correct manner. Manufacturers must work with the different forums, such as the Commission, Tribunal, and MIOSA, in the handling of complaints and the development of their internal complaint handling process. This is even more so with the Code, which will hopefully come into operation soon. Manufacturers will then have to ensure that their internal complaint process complies with the provisions of the Code and that staff are, firstly, educated on the internal complaint process and secondly, that the process is then communicated effectively to consumers.

The consumer implications of this research highlight the fact that a consumer must be aware of the available complaint forums in order to make an educated choice when deciding which forum to use. However, even a consumer who is aware of the available forums may not receive adequate redress from the complaint forums available under South African law. Consumers may want to explore alternative non-legal procedures/forums to resolve their complaints. This could be driven by an urge to have the issue resolved quickly and in a cost-effective manner. This is not always possible to achieve in legal proceedings.

Additional research is required to determine the effectiveness of other complaint forums such as Facebook and Twitter. Furthermore, once the Code is finalised and approved, further research should be done to determine its impact on certain consumer complaint forums.

Finally, the Consumer Goods and Services Ombud is still in its infancy, which inevitably requires future research on the effectiveness of the Ombud as a consumer complaint forum.

\section{CONCLUSION}

It is trite that there are a multitude of complaint forums available to South African consumers. The available forums are illustrated in Figure 1 below.

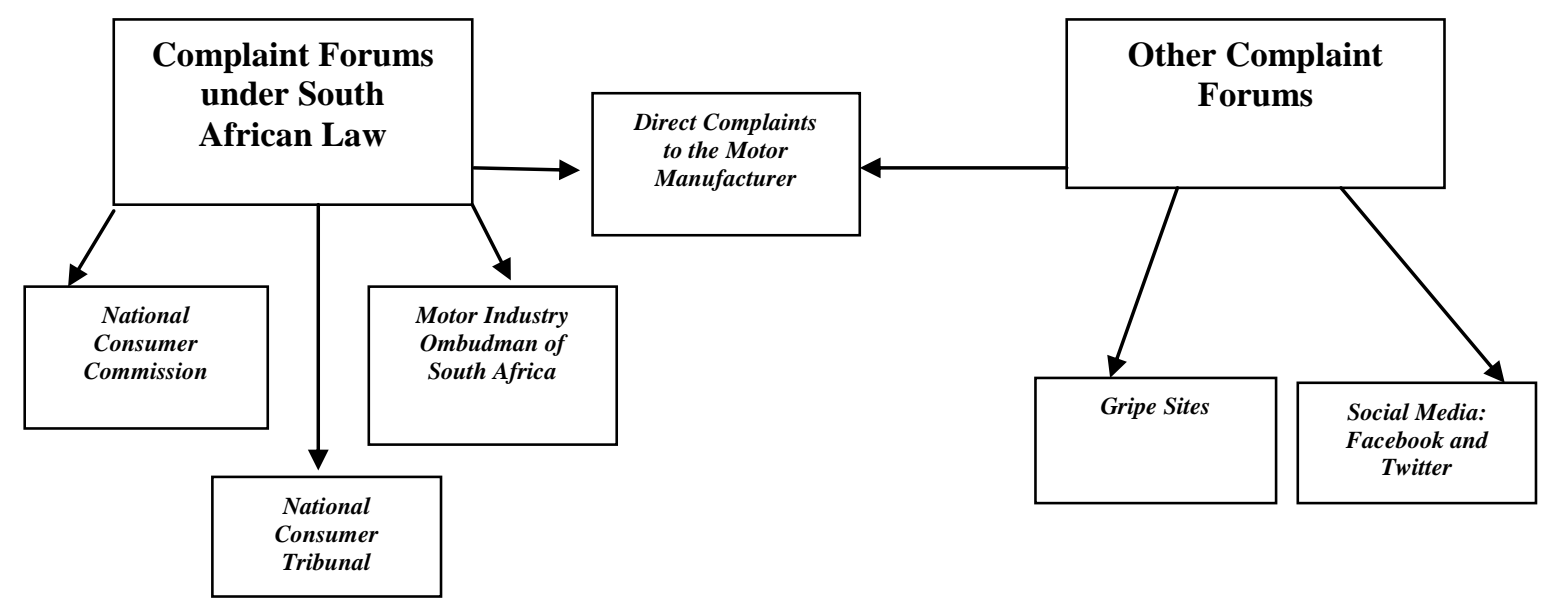

Figure 1: Complaint Forums Available to the South African Consumer in the Motor Service Industry 
Having so many complaint forums may lead to forum-shopping amongst consumers. Furthermore, even though a complaint may be referred to more than one forum in some instances, this will not always be possible. For example, a complaint cannot be referred to the Tribunal and Commission simultaneously.

Even when consumers are educated on the different complaint forums, a consumer may not be able to make use of a specific complaint forum due to either the complexity of the complaint procedure, the cost and time associated with the forum, or the ineffectiveness of that forum.

Non-legal complaint forums, like complaint websites, continue to be used by consumers. This may be due to the anonymous nature or relative ease with which a complaint can be submitted and brought to the attention of thousands, or perhaps in cases where the consumer only wants to release his or her frustration or anger due to the poor service delivery, but does not want to take the complaint further.

One can agree that the current state of complaint forums is not perfect. However, inroads have been made to improve the current structures, which is evident, inter alia, in the introduction of minimum complaint standards in the Code and improvements in the MIOSA complaint process over the last year. Further improvements will only be achieved through a concerted effort between industry players (which include the manufacturers, MIOSA and other watchdog organisations such as the RMI), consumers and ultimately law makers. Only through collaboration between all parties will South African consumers in the motor vehicle service industry be amongst the best protected consumers in the world.

\section{AUTHOR INFORMATION}

Michel M. Koekemoer holds the qualifications B Com (PU for CHE) (cum laude), LLB (PU for CHE) (cum laude), and LLM (Pret) (cum laude). She is a lecturer within the Department of Mercantile Law, School of Law, University of South Africa, and an admitted attorney of South Africa. E-mail: koekemm@unisa.ac.za

\section{REFERENCES}

1. Anon (2013, 10 June). Consumer good ombudsman appointed. Retrieved from http://www.moneyweb. co.za/moneyweb-south-africa/consumer-good-ombudsman-appointed?sn=2009\%20Detail

2. Barron, C. (2012, June 3). Business hopes commissioner is on her way. The Sunday Times.

3. Bailey, A. A. (2004). Thiscompanysucks.com: The use of the Internet in consumer-to-consumer articulations. Journal of Marketing Communications, 10(3), 169-182.

4. Berndt, A., \& Koekemoer, M. M. (2012). Online defamation and customer complaints. Journal of Digital Marketing, 3(1), 21-38.

5. Booi, M. (2011, September 8). Consumer commission gets 10,000 complaints. Eyewitness News. Retrieved from http://ewn.co.za/2011/09/08/Consumer-Commission-gets-10000-complaints

6. Bustos, L. (2009). Dealing with negative WOM online. Retrieved 12 March 2012 from http://www.heidimiller.com/2009/12/dealing-with-negative-wom-online.html

7. Cheales, P. (2013). Welcome to Peter Cheales. Retrieved May 29, 2013 from http://www.petercheales.co.za/about_content.htm

8. Davidow, M. (2003). Organizational responses to customer complaints: What works and what doesn't. Journal of Service Research, 5(3), 225-250.

9. Department of Trade and Industry. Fifth Draft Green Paper on the Consumer Policy Framework in par 4.1. Retrieved 26 May 2009 from http://www.dti.gov.za/ccrdlawreview/conslawdraftgreenpaper/7ChapterFour pdf

10. Hellopeter.com (2013). Comments on the National Consumer Commission. Retrieved 16 April 2013 from $\mathrm{http} / / /$ hellopeter.com/national-consumer commission/reports?company=782864\&since=\&datefrom=201204-16\&dateto $=2013-0416 \&$ problem $=$ Feedback $+\% 2 F+$ Response\&inclination=1\&title=Nature + of + complaints\%3AFeedback $+\% 2 \mathrm{~F}+$ Response \&advsearch=Submit

11. Hellopeter.com (2013). Comments on the RMI. Retrieved 25 June, 2013 from http://hellopeter.com/rmi/compliments-and-complaints 
12. Hellopeter.com (2013). Companies who respond. Retrieved 3 July 2013 from http://hellopeter.com/companies-who-respond?

13. Hoffman, K. D., Bateson, J. E. G., Wood, E. H., \& Kenyon, A. K. (2009). Services marketing concepts, strategies and cases $\left(3^{\text {rd }}\right.$ ed). Australia: South-Western Cengage Learning.

14. Peugeot Citroen South Africa (PTY) LTD t/a t/a Citroen South Africa v National Consumer Commission Case No: NCT/4062/2012/101 (1) (P) (date of hearing 3 August 2012).

15. Jacobs, W., Stoop P. N., \& Van Niekerk, R. (2010). Fundamental consumer rights under the Consumer Protection Act 68 of 2008: A critical overview and analysis. Potchefstroomse Elektroniese Regsblad, 13(3), 305-406.

16. Let the seller beware. (2009, February 13). The Financial Mail. Retrieved from http://www.fm.co.za/fm/2009/02/13/new-consumer-empowerment

17. Motor Industry Ombudsman of South Africa (2012). Newsletter of the Motor Industry Ombudsman of South Africa. From the desk of the Ombud, 4(3) 1-6. Retrieved May 21, 2013 from http://www.miosa.co.za/

18. Motor Industry Ombudsman of South Africa (2011). MIOSA Annual Report 2011. Retrieved 29 May, 2013 from http://www.miosa.co.za/

19. National Association of Automobile Manufacturers of South Africa. (2013) Member list for National Association of Automobile Manufacturers of South Africa. Retrieved May 29, 2013 from http://www.naamsa.co.za/members/

20. National Consumer Commission (2013). Complaint procedure. Retrieved 29 May 2013 from http://www.nccsa.org.za/complaints.html

21. National Consumer Commission. (2012). A progress report for the National Consumer Commission presented to the portfolio committee on trade and industry on 24 January 2012. Retrieved 29 May, 2013 from http://discover.sabinet.co.za/document/PLD38086

22. National Consumer Tribunal. (2011). Annual Report 2011. Retrieved 29 May, 2013 from http://www.thenct.org.za/NCTDocs/annual-reports/546b3322-6b93-4a16-a502-9f6a9117933d.pdf

23. Retail Motor Industry Organisation. (2013). File a complaint. Retrieved 17 May,2013 from http://www.rmi.org.za/file-a-complaint/\#Complaints

24. South African Board of Sheriffs (2013) Guide to Sheriff's fees charged in the magistrate's court. Retrieved 3 July 2013 from http://www.sheriffs.org.za/pdf/Fees_tariffs_tariffs_(mag)_FA.pdf

25. South Africa (2013). Draft South African Automotive Industry Code of Conduct: General Notice 113 of 2013. Government Gazette 36114, 15 February 2013.

26. South Africa (2008). The Consumer Protection Act 68 of 2008.

27. South Africa (2005). The National Credit Act 34 of 2005.

28. Harrison-Walker, L. J. (2001). E-complaining: A content analysis of an Internet complaint forum. Journal of Services Marketing, 15(5), 397-412.

29. Zeithaml, V. A., Bitner, M. J., \& Gremler, D. D. (2006). Services marketing: Integrating across the firm. Boston: McGraw-Hill. 